\title{
Sjögren Sendromu Ön Tanısı ile Minör Tükürük Bezi Biyopsisi Yapılan Hastalarda Biyopsi Sonuçlarıyla Serolojik Testlerin Karşılaştırılması
}

\author{
Comparison of the Minor Salivary Gland Biopsy Results and \\ Serological Tests in Patients Performed Minor Salivary Gland \\ Biopsy with Preliminary Diagnosis of Sjögren Syndrome
}

Sevcan UĞUR

Alanya Alaaddin Keykubat Üniversitesi Fiziksel Tıp ve Rehabilitasyon Anabilim Dalı, Romatoloji Bilim Dalı Antalya, Türkiye

Yazışma Adresi

Correspondence Address

\section{Sevcan UĞUR}

Alanya Alaaddin Keykubat Üniversitesi Fiziksel Tip ve Rehabilitasyon Anabilim Dalı, Romatoloji Bilim Dalı Antalya, Türkiye

E-posta:

dr_sevcanugur@hotmail.com

Geliş tarihi \ Received : 06.05.2020 Kabul tarihi \Accepted : 08.07.2020 Elektronik yayın tarihi $\quad: 12.07 .2021$ Online published

Bu makaleye yapılacak atıf: Cite this article as:

Uğur S. Sjögren sendromu ön tanısı ile minör tükürük bezi biyopsisi yapılan hastalarda biyopsi sonuçlarıly serolojik testlerin karşılaştırılması. Akd Tıp D 2021; 7(2):239-243

Sevcan UĞUR

ORCID ID: 0000-0001-5617-629X

\section{ÖZ}

Amaç: Sjögren sendromu egzokrin bezlerin lenfositik infiltrasyonu ile karakterize otoimmün inflamatuvar bir hastalıktır. Sjögren sendromu için çeşitli serolojik testler, semptomlar, histopatolojik bulguları içeren farklı sınıflandırma kriterleri bulunmaktadır. Bu çalışmada minör tükürük bezi biyopsi sonuçları ile serolojik özellikler arasındaki ilişkinin değerlendirilmesi amaçlandı.

Gereç ve Yöntemler: Minör tükürük bezi biyopsisi ile anti nükleer antikor, ekstrakte nükleer antijen, anti dense fine speckled 70 antikor sonuçları arasındaki ilişki değerlendirildi. İstatistiksel önemlilik için $\mathrm{p}<0,05$ ise anlamlı kabul edildi.

Bulgular: Çalışmaya 77 hasta $(71 \mathrm{~K}, 6 \mathrm{E})$ dahil edildi. Hastaların \%22,1'inde anti nükleer antikor dense fine speckled paterndeydi. Hastaların \%31,2'sinde biyopsi sonucu histopatolojik olarak kesin Sjögren sendromu ile uyumluydu (fokus skoru $\geq 1$ ). Hastaları $\% 19,5$ 'inde anti dense fine speckled 70 antikor, \%26'sında anti SS-A antikor pozitifti. Anti dense fine speckled 70 antikor pozitifliği olan 15 hastanın 7'si Sjögren sendromu tanısı aldı. Anti dense fine speckled 70 antikor pozitif ve negatif hastalar arasında Sjögren sendromu tanısı açısından ve biyopsi pozitifliği açısından fark yoktu $(\mathrm{p}=0,905, \mathrm{p}=0,996)$.

Sonuç: Minör tükürük bezi biyopsisi Sjögren sendromu tanısında çok önemli bir yere sahiptir. Anti nükleer antikor, anti SS-A ve anti SS-B antikorları negatif olan hastalarda minör tükürük bezi biyopsisi Sjögren sendromu tanısı koyma şansı vermektedir. Tek başına anti dense fine speckled 70 antikor pozitifliği Sjögren sendromu tanısını dışlamamaktadır.

Anahtar Sözcükler: Anti dense fine speckled antikor, Minör tükürük bezi biyopsisi, Sjögren sendromu

\begin{abstract}
Objective: Sjogren's syndrome is an autoimmune inflammatory disease characterized by lymphocytic infiltration of the exocrine glands. There are various classification criteria for Sjögren's syndrome which include various serological tests, symptoms, and histopathological findings. In this study, it was aimed to evaluate the relationship between minor salivary gland biopsy results and serological features. Material and Methods: The relationship between minor salivary gland biopsy and anti-nuclear antibody, extracted nuclear antigen, and the dense specled antibody results were evaluated. $\mathrm{P}<0.05$ was considered significant.

Results: 77 patients $(71 \mathrm{~F}, 6 \mathrm{M})$ were included in the study. In $22.1 \%$ of the patients the anti-nuclear antibody was in a fine speckled pattern. The $31.2 \%$ of the patients was histopathologically compatible with Sjögren syndrome (focus score $\geq 1$ ). Anti dense fine speckled 70 antibody was positive in $19.5 \%$ of the patients and anti SS-A antibody in $26 \%$. Seven of the 15 patients with anti dense fine speckled 70 antibody positivity were diagnosed with Sjögren's syndrome. There was no difference between anti dense fine speckled 70 antibody positive and negative patients in terms of diagnosis of Sjögren's syndrome and biopsy positivity $(\mathrm{p}=0.905, \mathrm{p}=0.996)$.

Conclusion: Minor salivary gland biopsy has very important place in diagnosis of Sjögren syndrome. Minor salivary gland biopsy gives the chance to diagnose Sjögren's syndrome in patients with negative anti nuclear antibodies, anti SS-A and anti SS-B antibodies. Isolated anti dense fine speckled 70 antibody positivity does not exclude Sjögren syndrome.
\end{abstract}

Keywords: Anti dense fine speckled 70 antibody, Minor salivary gland biopsy, Sjögren's syndrome 


\section{GİRIŞ}

Sjögren sendromu(SS) egzokrin bezlerin lenfositik infiltrasyonu ile karakterize etyolojisi bilinmeyen, otoimmün inflamatuvar bir hastalıktır. Salgı bezleri hastalıkta en çok etkilenen organlardır (1). Ağırlıklı olarak lakrimal ve tükürük bezleri etkilenir, ağız kuruluğu ve göz kuruluğuna neden olur (2). SS için çeşitli sınıflandırma kriterleri bulunmaktadır. Bu sınıflandırma kriterlerinin bazılarında laboratuvar testleri baskınken, bazılarında ise kuru göz ve kuru ağız semptomları baskınlığı ve biyopsi veya otoantikor gerekliliği bulunmaktadır (3).

SS tanısı için tek başına yeterli bir klinik kriter ya da laboratuvar testi bulunmamaktadır. 2002 American European Consensus Group (AECG) SS sinıflandırma kriterleri: 1. Kuru göz semptomları, 2. Ağız kuruluğu semptomları, 3. Kuru göz bulguları (Schirmer veya Rose Bengal testlerinin anormal olması), 4. Tükürük bezi fonksiyon testleri (anormal akım hızı, sintigrafi veya sialogram), 5. Minör tükürük bezi biyopsisi (fokus skoru $\geq 1$ ), 6. Otoantikor pozitifliğini (anti-SS-A veya anti-SS-B antikor) temel alır. Hastanın SS olarak sınıflandırılması için bu altı kriterden en az dördü pozitif olmalıdır. Histopatolojik ve serolojik kriterlerden birisinin de mutlaka bulunması gerekir (4). Amerikan Romatoloji Koleji (ACR) Sjögren Uluslararası Klinikler İşbirliği Kurumu (SICCA) tarafindan yayınlanan sınıflandırma kriteri ise objektif bulgulara dayanmaktadır. Serolojik testler (anti-SSA ve/veya anti-SS-B veya pozitif romatoid faktör ve $A N A \geq 1 / 320$ ), oküler boyanma skorunun $\geq 3$ olması ve fokal lenfositik sialoadenit (fokus skoru $\geq 1 / 4 \mathrm{~mm}^{2}$ ) parametrelerini temel alan 2012 ACR kriterlerine göre bu parametrelerden en az ikisinin bulunduğu hastalar SS olarak siniflandirılır (5).

SS'de göz tutulumunun gösterilmesinde kullanılan yöntemler için fikir birliği sağlanmış olmasına rağmen ağız kuruluğunun belirlenmesinde sağlanamamıştır. Sintigrafi, siyalografi tükürük akım hızı (uyarılmış/uyarılmamış) ve minör tükürük bezi biyopsisi tükürük bezi tutulumunun değerlendirilmesinde kullanılan tanısal testlerdir (6).

SS'de histopatolojik sinıflama Chisholm ve Mason tarafindan tanımlanmıştır. Histopatolojik değerlendirme 0-4 arasında derecelendirilerek yapılır. Bu sinıflandırmaya göre evre 0; inflamatuvar infiltrasyon yok, evre 1; hafif infiltrasyon, evre 2; orta düzeyde lenfositik infiltrasyon var ancak fokus yok, evre 3; bir tane fokus ve evre 4; birden fazla fokus olmasını belirtmektedir (7). Bu çalışmada SS ön tanısı ile minör tükürük bezi biyopsisi yapılan hastalarda minör tükürük bezi biyopsi sonuçları ile serolojik özellikler arasındaki ilişkiyi değerlendirerek minör tükürük bezi biyopsisinin ve anti dense fine speckled 70 antikorunun (anti-DFS70 antikoru) SS tanısı koymadaki öneminin gösterilmesi amaçlandı.

\section{GEREÇ VE YÖNTEM}

Bu çalışmada Temmuz 2017-Kasım 2019 tarihleri arasinda Romatoloji kliniğine ağız kuruluğu, göz kuruluğu ve eklem ağrısı şikayeti ile başvurmuş ve schirmer testi ile göz kuruluğu tanısı konulmus,, SS ön tanısıyla Romatoloji kliniğinde minör tükürük bezi biyopsisi yapılmış hastaların dosyaları retrospektif olarak değerlendirildi. Hastalara ait yaş, cinsiyet gibi demografik özellikler, anti nükleer antikor (ANA), ekstrakte nükleer antijen (ENA) sonuçları, eritrosit sedimentasyon hızı (ESH), G-reaktif protein (CRP) ve minör tükürük bezi biyopsi rapor sonuçları hastane elektronik kayıt sisteminden alındı. ANA indirekt immün florosan (IIF) yöntemi ile değerlendirildi. ENA profili tetkikinde Immun Blot (IB) yöntemiyle değerlendirilmiş anti-DFS70 antikoru, anti SS-A ve anti SS-B ve diğer nükleer antikor sonuçları kaydedildi. Minör tükürük bezi biyopsilerinde 4 $\mathrm{mm}^{2}$ lik alanda her biri 50 veya daha fazla sayıda lenfosit içeren en az bir odak bulunması (fokus skoru) SS'nin kesin histopatolojik tanı kriteri olarak kabul edildi. Buna karşın bu kriterleri karşlamayan, genellikle hafif düzeyde lenfositik/ lenfoplazmositer inflamatuvar hücre infiltrasyonu bulunan olgular hafif inflamasyon olarak kabul edildi. Lenfositik agregasyon odağı gözlenen ancak fokus skoru oluşturacak sayıda lenfosit içermeyen hastalar kaydedildi. Bu çalışmada 2002 AECG SS sinıflandirma kriterleri (4) temel alınarak ağız ve göz kuruluğu semptomu olan ve göz kuruluğu saptanan hastalardan minör tükürük bezi biyopsisinde fokus skoru $\geq 1$ ve/veya otoantikor pozitifliği (anti-SS-A veya anti-SS-B antikor) olan hastalar SS olarak sinıflandırıldı. İstatistiksel analizlerin tümünde IBM-SPSS16 kullanıldı. İstatistiksel önemlilik için $\mathrm{p}<0.05 i$ ise anlaml kabul edildi. Bu çalışma için Balıkesir Üniversitesi Tıp Fakültesi Etik Kurulu'ndan (04.12.2019 tarih ve 2019/198 sayll karar) onay alındı. Çalışma Helsinki Bildirgesi ilkelerine uygun olarak gerçekleştirildi.

\section{BULGULAR}

$\mathrm{Bu}$ çalışmada Romatoloji kliniğinde SS ön tanısı ile minör tükürük bezi biyopsisi yapılmış 80 hastanın elektronik dosyaları incelendi. Üç hastanın ANA sonucu elektronik ortamda kayıtlı olmadığı için çalışma dışı bırakıldı. Çalışmaya 77 hasta $(71 \mathrm{~K}, 6 \mathrm{E})$ dahil edildi. Yaş ortalaması

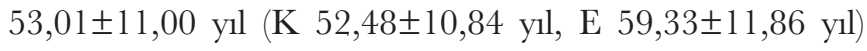
idi. Kadın ve erkek hastalar arasında yaş açısından istatistiksel olarak fark yoktu ( $>>0,05)$. Hastaların \%15,6'sında ANA negatifti. Hastaların 31 'inde $(\% 40,3)$ ANA $\geq 1 / 160$ titre, 18'inde $(\% 23,4)$ ANA $\geq 1 / 320$ titre, 11 'sinde $(\% 14,3)$ ANA $\geq 1 / 640$ titre, 5 'inde $(\% 6) \quad$ ANA $\geq 1280$ titre idi. ANA hastaların 33'ünde $(\% 42,9)$ granüler, 17 'sinde $(\% 22,1)$ dense fine speckled patern (DFS), 11 'inde $(\% 14,3)$ homojen, 2'sinde $(\% 2,6)$ nükleolar boyanma gösteriyordu. Hastaların \%19,5'inde IB anti DFS70 antikor pozitifti. Çalışmaya katılan hastaların 13'ünde $(\% 16,9)$ anti DFS70 antikor 
tek başına pozitifti, 2 hastada ise anti SS-A antikorla birliktelik gösteriyordu. IIF DFS70 ANA paterni gösteren 17 kişinin 7'sinde $(\% 41,2)$ anti DFS70 antikoru pozitifti. Bu çalışmada hastaların 20'sinde (\%26) anti SS-A antikor pozitifti. Hastaların 24 'ünde $(\% 31,2)$ biyopsi sonucu histopatolojik olarak kesin SS ile uyumluydu (fokus skoru $\geq 1$ ). Kırk bir hastanın biyopsisinde hafif lenfosit infiltrasyonu vardı, 4 hastanın ise biyopsisinde lenfosit infiltrasyonu odak oluşturmakla birlikte lenfosit sayısı $<50$ idi. Sekiz hastanın biyopsisi normal tükürük bezi dokusu olarak raporlanmıştı. IIF DFS70 ANA pozitif olan 17 hastanın 4'ü histopatolojik olarak kesin SS ile uyumluydu, anti SS-A/SS-B antikorları negatifti. IB ENA profilindeki antikorların dağılımı tablo 1'de gösterilmiştir. Hastaların 37'si 2002 AECG SS sinıflandırma kriterlerine göre SS olarak sinıflandırıldı. 2002 AECG kriterlerine göre SS olarak sinıflandırılan hastaların 24'ünün biyopsisi histopatolojik olarak kesin SS ile uyumluydu (fokus skoru $\geq 1$ ). On üç hastada ise biyopsi kesin SS ile uyumlu olmamasına rağmen serolojik testlerle SS sinıflandırma kriterlerini karşllyordu. Yedi hasta ise hem histopatolojik hem de serolojik olarak 2002 AECG SS sınıflandırma kriterlerini karşılıyordu.

Anti DFS70 antikor pozitif hastaların \%33,3'ünde biyopsi SS ile uyumluydu (fokus skoru $\geq 1$ ), $\% 60$ 'mda ise hafif inflamasyon vardı. Anti DFS70 antikor pozitifliği olan 15 hastanın 7'si SS tanısı aldı, bu hastalarda 5'inde izole anti DFS70 pozitifliği vardı ve biyopsi histopatolojik olarak SS ile uyumluydu (fokus skoru $\geq 1$ ). İki hastada ise anti DFS70 pozitifliği ile birlikte anti SS-A antikor pozitifliği vard, bu iki hasta serolojik olarak SS olarak sinıflandırılmasına rağmen histopatolojik değerlendirme kesin SS (fokus skoru $\geq 1$ ) ile uyumlu değildi. Anti DFS70 antikor pozitif ve negatif hastalar arasında SS tanısı açısından ve biyopsi pozitifliği açısından fark yoktu $(p=0,905, p=0,996)$. Tükürük bezi biyopsisi kesin SS ile uyumlu (fokus skoru $\geq 1$ ) olan 24 hastanın 5'inde $(\% 20,8)$ anti DFS70 antikor, 4'ünde $(\% 16,7)$ yalnız anti SS-A antikor, 2'sinde (\%8,3) hem anti SS-A hem de SS-B antikorlar pozitifti. Anti DFS70 antikor durumu ile SS ilişkisi tablo 2'de gösterilmiştir. Tükürük bezi biyopsisi SS ile uyumlu hastaların otoantikor dağılımı tablo 3'de gösterilmiştir.

Bu çalışmada anti SS-A antikor pozitifliği olan hastaların \%35'inde minör tükürük bezi biyopsisi SS ile uyumluydu (fokus skoru $\geq 1$ ), \%45'inde tükürük bezinde hafif lenfositik infiltrasyon, \%10'unde ise lenfosit infiltrasyon odak oluşturacak kadar olmasina rağmen $4 \mathrm{~mm}^{2}$ lik alanda lenfosit sayısı $<50$ idi. İki hastada (\% 10) anti SS-A pozitif olmasına rağmen tükürük bezi biyopsi histopatolojik değerlendirmesi tamamen normaldi. Anti SS-A antikor pozitif ve negatif olan hastalarda biyopsi pozitifliği açısından istatistiksel olarak anlamlı bir fark yoktu $(\mathrm{p}=0,642)$. Bu çalışmada ortalama ESH $31,77 \pm 20,38 \mathrm{~mm} / \mathrm{saat}$ CRP 0,709 $\pm 0,959 \mathrm{mg} /$
dL idi. SS olan hastalarda ESH 29,58 $\pm 19,36 \mathrm{~mm} / \mathrm{saat}$, SS olmayanlarda $33,90 \pm 21,36 \mathrm{~mm} / \mathrm{saat}$ idi $(\mathrm{p}=0,356)$, CRP SS olan hastalarda $0,625 \pm 1,038 \mathrm{mg} / \mathrm{dL}, \mathrm{SS}$ olmayanlarda $0,791 \pm 0,881 \mathrm{mg} / \mathrm{dL}$ idi $(\mathrm{p}=0,452)$. Bu çalışmada 4 hastanın IIF ANA ve IB ENA profili negatif olmasına rağmen biyopsi histopatolojik olarak SS ile uyumluydu (fokus sko$\mathrm{ru} \geq 1$ ).

\section{TARTIŞMA}

Bu çalışmaya ağız ve göz kuruluğu semptomları olan, göz kuruluğu (schirmer testi< $5 \mathrm{ml} / 5$ dakika) saptanan hastalar

\section{Tablo I: IB otoantikor dağılım sıklı̆̆ı.}

\begin{tabular}{lc}
\hline Antikor Tipi & Antikor Pozitifliği \\
\hline İzole Anti DFS70 antikor & $13(\% 16,9)$ \\
\hline Anti SS-A antikor & $9(\% 11,7)$ \\
\hline Anti SS-A/PMSCL antikor & $2(\% 2,6)$ \\
\hline Anti SS-A/SS-B antikor & $5(\% 6,5)$ \\
\hline Anti SS-A/Anti DFS70 antikor & $2(\% 2,6)$ \\
\hline Anti SS-A/AMA antikor & $1(\% 1,3)$ \\
\hline Anti SS-A/Anti SM antikor & $1(\% 1,3)$ \\
\hline Anti SM/RNP antikor & $1(\% 1,3)$ \\
\hline AMA/SCL70 antikor & $1(\% 1,3)$ \\
\hline Anti JO1/PMSCL antikor & $1(\% 1,3)$ \\
\hline Anti Sentromer antikor & $1(\% 1,3)$ \\
\hline Anti Mitokondriyal antikor & $3(\% 3,9)$ \\
\hline
\end{tabular}

Tablo II: Anti DFS70 antikor ve Sjögren sendromu ilişkisi.

\section{Anti DFS70 Anti DFS70 antikor pozitif antikor negatif}

\begin{tabular}{lcc}
$\begin{array}{l}\text { Sjögren Sendromu } \\
\operatorname{var}(\mathrm{n}=37)\end{array}$ & $7(\% 18,9)$ & $30(\% 81,1)$ \\
\hline $\begin{array}{l}\text { Sjögren Sendromu } \\
\text { yok }(\mathrm{n}=40)\end{array}$ & $8(\% 20)$ & $32(\% 80)$ \\
\hline
\end{tabular}

Tablo III: Tükürük bezi biyopsisi Sjögren sendromu ile uyumlu hastaların IB otoantikor sıklığı.

Antikor Tipi

Tükürük bezi biyopsisinde fokus skoru $\geq 1$ olan hastalarda antikor pozifliği

\begin{tabular}{ll}
\hline İzole Anti DFS70 antikor & $5(\% 20,8)$ \\
\hline İzole Anti SS-A antikor & $4(\% 16,7)$ \\
\hline Anti SS-A/SS-B antikor & $2(\% 8,3)$ \\
\hline Anti SS-A/PMSCL antikor & $1(\% 4,2)$ \\
\hline İzole PMSCL antikor & $1(\% 4,2)$ \\
\hline Anti Mitokondriyal antikor & $1(\% 4,2)$ \\
\hline
\end{tabular}


dahil edildiği için çalışmaya dahil edilen tüm hastalar 2002 AECG SS sinıflandırma kriterinin 1, 2, 3. parametrelerini karşılamaktaydı. Bu çalışmada 24 hasta histopatolojik olarak kesin SS tanısı aldı. 13 hasta ise biyopsi negatif olmasına rağmen serolojik pozitiflik ve klinik uyumluluk nedeniyle SS tanısı aldı. Anti SS-A antikor pozitifliği olan 20 hastanın \%35'inde histopatolojik olarak fokus skoru $\geq 1, \% 45$ inde hafif inflamasyon vardı. Kessel ve arkadaşları biyopsi ile değerlendirdikleri 41 hastanın 16'sının SS tanısını karşıladığını, anti-Ro/LA antikor pozitifliği olan 12 hastanın 11'inin biyopsisinin pozitif olduğunu bulmuşlar ve anti-Ro/La nın biyopsi pozitifliği için pozitif prediktif değerini \%92 olarak belirtmişlerdir. Sikka sendromu olan hastaların ilk olarak anti-Ro ve anti-La antikorlar açısından değerlendirilmesi gerektĭgini, birinin pozitifliği durumunda ise biyopsiye gerek olmadan SS tanısının koyulabileceğini belirtmişlerdir (3). Bu çalışmada ise anti SS-A antikor pozitif olan hastaların yaklaşı \%35'inde biyopsi kesin olarak pozitifti. Histopatolojik olarak SS tanısı alan hastalarm ise 4'ünde $(\% 16,7)$ izole anti SS-A, 2'sinde $(\% 8,3)$ hem anti SS-A hem de SS-B antikor, l'inde anti SS-A ve PMSCL antikor pozitifliği vardı. Bu çalışmanın diğer önemli noktası ANA ve anti SS-A antikor negatif olsa bile biyopsinin histopatolojik olarak SS tanısı ile uyumlu olabilmesiydi. Ayrıca hastaların çok büyük bir kısmında tükürük bezinde patolojik evrelere ulaşmasa da inflamasyona ait bulgular vardı. Kılıç ve arkadaşları 671 minör tükürük bezi biyopsisi yapılmış hastaların 61'ine ortalama 15,6 $\pm 13,0$ ay sonra tekrar minör tükürük bezi biyopsisi yapıldığında sırasıyla $9(\% 14,8)$ ve $5(\% 8,2)$ hastada biyopsi derecelerinin 3 ve 4 olduğunu belirtmişlerdir. Illk biyopside tanısal olmayan sonuçların 2 . biyopsi sonucunda tanısal olabileceğini belirtmişlerdir (8). Bu çalışmada 24 hastanın biyopsisi histopatolojik olarak kesin SS'yi karşılarken geri kalan büyük çoğunluğunda ise biyopside inflamasyon bulguları olmasına rağmen Chilsom ve Mason'a göre evre $\leq 2$ idi. Çalışmaya dahil edilen hastaların büyük çoğunluğunda tükürük bezi biyopsisinde lenfositik infiltrasyon olmasına rağmen kesin olarak SS tanısı alacak düzeyde olmaması lenfositik infiltrasyonun tükürük bezlerini bölgesel olarak tutmasından kaynaklanıyor olabilir. Diğer yandan bu çalışmada histopatolojik olarak fokus skoru $\geq 1$ olmayan çok sayıda hastanın biyopsisinde inflamatuvar değişikliklerin bulunması hastaların ilerleyen zamanda biyopsilerinin tekrarlanması durumunda histopatolojik olarak SS tanısı alabileceğini düşündürmektedir. Bu çalışmada hastaların yaklaşı 1/3'ünün histopatolojik olarak kesin SS tanısı alması, diğer yandan serolojik tetkikleri negatif olan hastaların büyük çoğunluğunda tükürük bezinde patolojik evrelere ulaşmayan lenfositik infiltrasyonların görülmesi tükürük bezi biyopsisinin tanıdaki önemli yerini desteklemektedir.

Son y1llarda DFS70 ve anti DFS70 antikorların romatizmal hastalıklarla ilişkisini değerlendiren çeşitli çalışmalar bulun- maktadır. Mariz ve arkadaşları ANA pozitif sağlıklı kişilerin \%33.1'inde DFS paterni saptamışlar ve nükleer DFS paterninin sadece sağlıklı kontrollerde olduğunu belirtmişlerdir (9). Watanabe ve arkadaşları 597 sağllklı hastane çalışanının \%20'sinde ANA pozitifliği saptamıșlar, sağlıklı kișilerin $\% 11$ 'inde, ANA pozitiflerin ise \%54'ünde anti DFS 70 antikor pozitifliği bulmuşlardır (10). Anti DFS70 antikorunun izole varlığında ise ANA ilişkili romatizmal hastalık olasılığının azaldığı, anti-DFS70 antikor pozitifliğinin sikka semptomları olan ANA pozitif, anti SS-A antikoru negatif kişilerin ayırıcı tanısında yardımcı olabileceği belirtilmiştir (11). Muro ve arkadaşları Anti-DFS70 antikor pozitifliğini 500 otoimmün romatizmal hastalığa sahip bireyde araştırmışlar. Tüm hastaların 22'sinde $(\% 4,4)$, SS'ye sahip 71 hastanın ise 8'inde anti-DFS70 antikor pozitifliği saptamışlardır. Anti-DFS70 antikor pozitifliği saptanan 8 hastanın 5 'inde anti-SS-A, l'inde anti-SS-A ve anti-SS-B birlikteliği, l'inde anti-SS-A ve antiU1-RNP antikor pozitifliği varken sadece 1 hastada diğer antikorlar olmadan anti-DFS70 antikorunun izole pozitifliği olduğunu belirtmişlerdir (12).

Bu çalışmanın önemli noktalarından birisi biyopsisi histopatolojik olarak kesin SS ile uyumlu hastalarm \%20,8’inde izole anti DFS70 antikor pozitifliği vardı. Bu çalışmada anti DFS70 antikor pozitif ve negatif hastalarda SS açısından istatistiksel olarak anlamlı bir fark olmaması izole anti DFS70 antikor pozitifliğinin SS'yi dışlamadığını düşündürmektedir. Sikka semptomları olan hastalarda izole anti DFS70 pozitifliği olsa bile SS'nin ayırıcı tanıda mutlaka düşünülmesi gerektiğini göstermektedir.

\section{SONUÇ}

İnvaziv bir işlem olmasına rağmen minör tükürük bezi biyopsisi SS tanısında çok önemli bir yere sahiptir. ANA, anti SS-A ve anti SS-B antikorları negatif olan hastalarda tükürük bezi biyopsisi SS tanısı koyma şansı vermektedir. Sikka semptomları olan hastalarda serolojik testler her zaman tükürük bezi biyopsisi sonuçlarıyla uyumlu olmayabilir. Sikka semptomları olan hastalarda serolojik testler negatif olsa bile SS ayırıcı tanıda mutlaka düşünülmelidir. Sikka semptomları olan hastalar izole anti-DFS70 antikor pozitifliği olsa bile SS tanısı alabilirler bu hastalara klinik şüphe varlığında tükürük bezi biyopsisi yapılması SS tanı koyabilmeyi sağlar. $\mathrm{Bu}$ çalışma tek başına anti-DFS70 antikor pozitifliğinin SS tanısını dışlamadığını göstermesi açısından önemlidir. DFS70 pozitifliği ve İzole anti DFS70 antikor pozitifliği olan geniş hasta gruplarında yapılmış çalışmalara ihtiyaç bulunmaktadır.

Etik Komite Onayı: Bu çalışma için Balıkesir Üniversitesi Tıp Fakültesi Etik Kurulu'ndan (04.12.2019 tarih ve 2019/198 sayılı karar) onay alındı.

Çı1kar Çatışması: Yazarın çıkar çatışması yoktur.

Finansal Açıklama: Yazar bu çalışmada herhangi bir mali destek almamıştır. 


\section{KAYNAKLAR}

1. Aksoy T, Kiratli PO, Erbas B. Correlations between histopathologic and scintigraphic parameters of salivary glands in patients with Sjögren's syndrome.Clin Rheumatol 2012;31(9):1365-70.

2. Thorne I, Sutcliffe N. Sjögren's syndrome BrJ Hosp Med (Lond). 2017;78(8):438-42.

3. Kessel A, Toubi E, Rozenbaum M, Zisman D, Sabo E, Rosner I. Sjögren's syndrome in the community: can serology replace salivary gland biopsy? Rheumatol Int 2006;26(4):337-9.

4. Vitali C, Bombardieri S, Jonsson R, Moutsopoulos HM, Alexander EL, Carsons SE, Daniels TE, Fox PC, Fox RI, Kassan SS, Pillemer SR, Talal N, Weisman MH; Classification Criteria for Sjögren's Syndrome: A Revised Version of the European Criteria Proposed by the American-European Consensus Group European Study Group on Classification Criteria for Sjögren's Syndrome. Ann Rheum Dis 2002;61(6):554-8.

5. Shiboski SC, Shiboski CH, Criswell L, Baer A, Challacombe S, Lanfranchi H, Schiødt M, Umehara H, Vivino F, Zhao Y, Dong Y, Greenspan D, Heidenreich AM, Helin P, Kirkham B, Kitagawa K, Larkin G, Li M, Lietman T, Lindegaard J, McNamara N, Sack K, Shirlaw P, Sugai S, Vollenweider C, Whitcher J, Wu A, Zhang S, Zhang W, Greenspan J, Daniels T; Sjögren's International Collaborative Clinical Alliance (SICCA) Research Groups. American College of Rheumatology classification criteria for Sjögren's syndrome: a data-driven, expert consensus approach in the Sjögren's International Collaborative Clinical Alliance cohort Arthritis Care Res (Hoboken) 2012;64(4):475-87.
6. Yazisiz V, Avci AB, Erbasan F, Kiriş E, Terzioğlu E. Diagnostic performance of minor salivary gland biopsy, serological and clinical data in Sjögren's syndrome: a retrospective analysis Rheumatol Int 2009 ;29(4):403-9.

7. Chisholm DM, Mason DK: Labial salivary gland biopsy in Sjogren's disease. Chisholm DM, Mason DK.J Clin Pathol 1968;21(5):656-60.

8. Levent Kılıç, Umut Kalyoncu, İsmail Doğan, Bünyamin Kısacık1, Ömer Karadağl, ismail Taşkıran Şule Apraş Bilgen, Ali Akdoğan1, Sedat Kiraz, İhsan Ertenli, Meral Çalgüneri Sjögren sendromu tanısında minör tükürük bezi biyopsisinin tekrarı gerekir mi? RAED Dergisi 2012;4(1):6-10.

9. Mariz HA, Sato EI, Barbosa SH, Rodrigues SH, Dellavance A, Andrade LE. Pattern on the antinuclear antibody-HEp-2 test is a critical parameter for discriminating antinuclear antibody-positive healthy individuals and patients with autoimmune rheumatic diseases.Arthritis Rheum 2011; 63(1):191-200.

10. Watanabe A, Kodera M, Sugiura K, Usuda T, Tan EM, Takasaki Y, Tomita Y, Muro Y. Anti-DFS70 antibodies in 597 healthy hospital workers. Arthritis Rheum 2004;50(3):892-900.

11. Lee H, Kim Y, Han K, Oh EJ. Application of anti-DFS70 antibody and specific autoantibody test algorithms to patients with the dense fine speckled pattern on HEp-2 cells. Scand J Rheumatol 2016;45(2):122-8.

12. Muro Y, Sugiura K, Morita Y, Tomita Y. High concomitance of disease marker autoantibodies in antiDFS70/LEDGF autoantibody-positive patients with autoimmune rheumatic disease. Lupus 2008;17(3):171-6. 